\title{
Unanswered issues related to the COVID-19 pandemic
}

\author{
Sylwia Ufnalska ${ }^{1}$ (i) Eric Lichtfouse ${ }^{2}$ (i)
}

Published online: 3 May 2021

(C) The Author(s), under exclusive licence to Springer Nature Switzerland AG 2021

The coronavirus disease 2019 (COVID-19) pandemic has urged world nations to enforce rapid and sometimes very contradictory policies to limit the virus spread, with results ranging widely from total failure to moderate success. Besides the ironical defeat by such a small enemy, this clearly highlights the global disorganization of the society, which is mainly attempting to solve issues by treating the symptoms rather than the causes (Lichtfouse 2009) (Fig. 1). Because of the current pandemic, we tend to focus on shortterm methods supposed to prevent disease transmission. This gradually leads to catastrophic, unintended effects on the economy and on both our mental and physical health. Since, unfortunately, novel pandemics and climate crises are very likely to come, we urgently need to develop a long-term vision for more effective solutions such as the 'three Cs' strategy, which suggests avoiding crowded places, close-contact settings, and confined spaces (Ufnalska 2020a). Solutions include keeping away from indoor air pollution, promoting of a healthy lifestyle, fighting with addictions, fever phobia and bureaucracy, and other smarter cures (Ufnalska 2020a; Dai et al. 2021). In this context, we highlight below eleven vital challenges concerning environmental pollution, COVID-19-related health issues and our well-being.

1. Face masks and frequent hand washing or disinfection are major unintended sources of environmental pollution (Gorrasi et al. 2021) and can lead to allergies, skin irritation, and mental diseases. How can the use of face masks and hand hygiene be optimized, to minimize their disadvantages?

Sylwia Ufnalska

sywia.ufnalska@gmail.com

Eric Lichtfouse

eric.lichtfouse@gmail.com

1 Honorary Member of European Association of Science Editors (EASE), Poznań, Poland

2 Aix-Marseille Univ, CNRS, IRD, INRAE, Coll France, CEREGE, 13100 Aix en Provence, France
2. Drinking water reserves in many countries are very limited and exposed to pollution with faeces, pathogens, and chemicals. How can drinking water pollution be reduced?

3. Indoor air pollution with viruses (if anybody is infected), $\mathrm{CO}_{2}$, chlorine, xenoestrogens from moulds, and other substances, is a serious threat to our health. Does the "stay at home" policy truly have a positive effect on our health or disadvantages exceed the benefits?

4. COVID-19 patients breathe out large amounts of viruses, $\mathrm{CO}_{2}$ and many toxic compounds, while many types of oxygen masks allow mixing of exhaled and inhaled air. How can oxygen mask design be improved to minimize the pollution of inhaled air with exhaled air? For the same reason, when using face masks outdoors, would it be safer to uncover the nose (Ufnalska 2020b)?

5. Mechanical ventilation of COVID-19 patients through the mouth often leads to serious complications, such as bacterial infections and lung damage. Can any safer and more effective method of blood oxygenation be developed, e.g., through the nose, where air is naturally filtered, and nitric acid (NO) is released from nasal cavities to block viral replication (Åkerström et al. 2005), dilate the airways and blood vessels in lungs, and stimulate surfactant production (Ignarro 2020)?

6. Syringes are difficult to dispose of and have become a huge public health threat. Can oral vaccines be developed as a safer solution?

7. In winter, the concentration of $\mathrm{CO}_{2}$ in cities increases dramatically, mostly because of limited photosynthesis and air pollution due to heating. Can an increased proportion of green areas markedly reduce human mortality in densely populated regions?

8. Lawns are usually mown very often, leading to noise, environmental pollution, and limited abundance of both flowers and pollinating insects. Can lawns be mown less often, to increase the abundance of flow- 


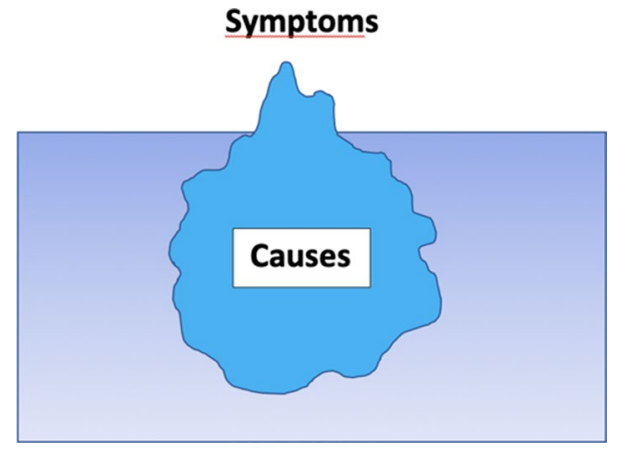

Fig. 1 The iceberg analogy showing that humans treat rather symptoms than causes, notably in crisis situations, such as pandemics

ers, bees, fruit, decrease environmental pollution, and produce more oxygen?

9. Woodlands and wetlands, which play a major role in reducing environmental pollution, are subject to fragmentation or even complete destruction in many areas. How can we protect vegetation more effectively?

10. Common medicinal herbs (like stinging nettle), due to the natural variation of their chemical composition, are generally excluded from evidence-based medicine, although some studies suggest their high antiviral potential (Kumaki et al. 2011; Kregiel et al. 2018). How can this problem be solved?

11. Last but not least: hugging is important for child development and for our well-being in general, but some experts claim that it is a serious threat during the pandemic. Is hugging only outdoors—without kisses—a good solution?

Researchers should pay more attention to all these problems and manage to find effective answers soon. They can greatly contribute to minimizing the drawbacks, and maximizing the positive effects of human activity on both our health and the environment. All this is necessary for a better future for our children and grandchildren.

\section{References}

Åkerström S, Mousavi-Jazi M, Klingström J, Leijon M, Lundkvist $\AA$, Mirazimi A (2005) Nitric oxide inhibits the replication cycle of Severe Acute Respiratory Syndrome coronavirus. J Virol 79:1966-1969. https://doi.org/10.1128/JVI.79.3.1966-1969.2005

Dai H, Han J, Lichtfouse E (2021) Smarter cures to combat COVID-19 and future pathogens: a review. Environ Chem Lett. https://doi. org/10.1007/s10311-021-01224-9

Gorrasi G, Sorrentino A, Lichtfouse E (2021) Back to plastic pollution in COVID times. Environ Chem Lett 19:1-4. https://doi.org/10. 1007/s10311-020-01129-z

Ignarro LJ (2020) The right way to breathe during the coronavirus pandemic. The Conversation. https://theconversation.com/theright-way-to-breathe-during-the-coronavirus-pandemic-140695

Kregiel D, Pawlikowska E, Antolak H (2018) Urtica spp.: ordinary plants with extraordinary properties. Molecules 23(7):1664. https://doi.org/10.3390/molecules23071664

Kumaki Y, Wandersee MK, Smith AJ, Zhou Y, Simmons G, Nelson NM, Bailey KW, Vest ZG, Li JK, Chan PK, Smee DF, Barnard DL (2011) Inhibition of severe acute respiratory syndrome coronavirus replication in a lethal SARS-CoV BALB/c mouse model by stinging nettle lectin Urtica dioica agglutinin. Antiviral Res 90(1):22-32. https://doi.org/10.1016/j.antiviral.2011.02.003

Lichtfouse E (2009) Climate change, society issues and sustainable agriculture. In: Lichtfouse E (ed) Climate change, intercropping, pest control and beneficial microorganisms. Sustainable Agriculture Reviews, vol 2. Springer, Berlin, pp 1-7. https://doi.org/10. 1007/978-90-481-2716-0_1

Ufnalska S (2020a) Physical activity outdoors as an alternative to lockdown: the Three Cs Strategy. Med Arch 74(5):399-402. https:// doi.org/10.5455/medarh.2020.74.399-402

Ufnalska S (2020b) Why not encourage physical activity outdoors and inhaling through the uncovered nose during the coronavirus lockdown? Mater Sociomed 32:315-316. https://doi.org/10.5455/ msm.2020.32.315-316

Publisher's Note Springer Nature remains neutral with regard to jurisdictional claims in published maps and institutional affiliations. 